\title{
Immigration law: a theological response
}

\author{
Robert W. Heimburger
}

31 Jan 2019 version accepted for the Sept. 2019 issue of Theology, to accompany responses by Margaret B. Adam and Therese Feiler.

Published version available at https://doi.org/10.1177/0040571X19858943

\begin{abstract}
This article presents the fruits of a dialogue between Christian ethics and immigration law found in the author's recent book God and the Illegal Alien: United States Immigration Law and a Theology of Politics (Cambridge: Cambridge University Press, 2018). That dialogue highlights the importance of the people of God as a migrant people and the destiny of the nations as coming together in the blood of Christ. The dialogue also highlights a church posture toward government that the control of immigration is to be undertaken only in a limited way that keeps in mind the purpose of migration controls to protect human life and no more. Finally, the dialogue highlights the importance of asking 'Who is my neighbour?', pointing Christians to recognise those foreigners who have shown them mercy. This dialogue began with US law, but a parallel dialogue with British law produces conclusions about living as a migrant church in the United Kingdom, about calling the Home Office to govern immigration humbly, and about recognizing love received from migrant neighbours.
\end{abstract}

\section{Keywords}

Migration, Christian ethics, church, government, neighbours, United Kingdom, politics

Immigration law and policy raise crucial questions today for the life of the church. Firstly, who is the church? Does the church identify primarily with settled residents or with migrants, even irregular migrants? Secondly, how does the church relate to civil authority? Does the church draw attention to Jesus as King of kings in the face of contested laws about immigration? Thirdly, for the church, who are our neighbours? How does the church respond to love and mercy shown by foreigners, even irregular migrants, and how does it show love and mercy in return?

These questions come from a dialogue with the laws of one country in my book God and the Illegal Alien: United States Immigration Law and a Theology of Politics (Cambridge: 
Cambridge University Press, 2018). That dialogue focused on legal history as notions of 'aliens', 'illegal aliens', and 'illegal aliens' from a neighbouring country developed in federal US law. This article will share that dialogue's fruits and its findings on immigration law and Christian ethics on the themes of the nations, Israel, and the church; on government; and on neighbours. Finally, the article will suggest where a similar dialogue with British immigration law would lead.

\section{Migrants, nations, Israel, and church}

In response to ways that civil authorities define people who come from far away, the church needs to re-examine where such people fit into God's work of creating and re-creating the world. Karl Barth proves a helpful guide on these questions as he interprets Scripture from Genesis to Ephesians. He affirms that members of the church hear God's command as members of a people or nation. It is right, then, for the church's members to value their people's history, language, and place. So, to a certain degree, seeking the good of one's nation is a way of responding to God's call. Yet peoples or nations are not fixed aspects of creation, says Barth, but temporary arrangements that God has provided. National belonging is 'pilgrim's clothing' that human beings put on and can take off again. ${ }^{1}$

What is the purpose of these temporary and fluid groupings called nations? Their aim is not to dissolve into a common humanity, a cosmopolitan identity with no distinctions. Instead, their aim is to draw near to one another in the body of Christ. The key to understanding nations, Barth suggests, is found in Ephesians. There, the letter writer affirms that the Gentiles were once alienated from Israel, 'but now in Christ Jesus you who once were far off have been brought near by the blood of Christ. For he himself is our peace, who has made us both one and has broken down in his flesh the dividing wall of hostility'. ${ }^{2}$ The destiny of the nations does not lie in some fully realised United Nations. Instead, the destiny of the nations lies in being grafted into Israel. Responsible life as a member of a nation, then, is outward looking, directed toward coming near to those who are far off. Migrants, then, are far off people who have come near. Settled Christians have a choice: will they draw near to these new neighbours or turn away from their neighbours?

Whatever choice settled Christians make, churches in cities like London and New York are already full of migrants and led by migrants. The phenomenon of migrant churches is not new; the earliest church grew under the leadership of migrant apostles, people 'sent out'. In 1 
Corinthians 9, the Apostle Paul gives a picture of his status as a migrant missionary. Paul is sent out, compelled to proclaim the good news (vv. 1, 16). He is completely free, and out of that freedom - in the reading of Brian Brock and Bernd Wannenwetsch - he enslaves himself to others so that he might share in the good news (vv. 1, 19, 23). ${ }^{3}$ He becomes all things to all people. Paul becomes like Jews and like Gentiles, integrating himself with those who live under the Jewish law and integrating himself with those who are not under the Jewish law. He can do all this because he stands within Christ's law (vv. 20-21). Paul is a migrant: he goes out across cultures and boundaries. He experiences the mix of acting and being acted upon (vv. 1, 20) that is shared with migrants who are too easily slotted into categories of forced migrants and economic migrants. Paul experiences the powerlessness and the vulnerability of the migrant, adapting to new cultures while knowing he can only be 'like' them (vv. 21-22).

Now, Paul's migration is a physical migration, when Barth's talk of 'pilgrim's clothing' has to do with a spiritual migration. (Dialogue with Therese Feiler has prompted me to distinguish these migrations that the church undergoes.) An apostle like Paul is a migrant not only in a spiritual sense. The one 'sent out' does something more than put on metaphorical 'pilgrim's clothing' on the way to the New Jerusalem. The apostle moves across borders of land and sea, language and culture in a literal sense. As the churches confess in the Apostle's Creed that they are an apostolic church, they remember the apostles, these migrant missionaries to whom they owe their existence. Beyond the apostles, many more in the church are sent out across boundaries of cultures and nation-states to proclaim the good news of Jesus Christ. In this sense, the church is in solidarity with migrants not only because they are fellow human beings. And the church is in solidarity with migrants not only because the church is on a spiritual journey toward the New Jerusalem. The church remembers, and she contains within her, people who are sent out to proclaim the gospel that Jesus died and is alive again. This means that as settled members of the church encounter those who migrate physically, the church is reminded of her apostolic heritage. Meetings with fellow migrants can sanctify the church and keep her from settling into place when the Spirit is moving her outward.

Encountering migrants those can bring Christians a new kind of freedom, a freedom to be on the move within the law of Christ. 


\section{Immigration governance}

Reckoning with immigration law leads to conclusions about the nations and the church, that the nations are destined to draw near to one another in Israel and that the church celebrates her own missionary migrants. What then should the church say about the role of civil authorities over immigration? Reading Scripture alongside Martin Luther and contemporary interpreters points toward an answer. In Genesis 2-4, a God-given human activity of keeping a place is turned into guarding places after the first instance of murder. In the beginning, human beings are tasked with keeping the garden, but as they are expelled and as Cain kills Abel, they build cities and guard cities to stop cycles of vengeance. Both 'keeping' and 'guarding' are expressed by the Hebrew šmr, so that keeping turns into guarding when a culture of killing requires the use of walls and arms. Though tragically deformed, the guarding of places looks forward to the new city of Revelation 21-22, a city that has walls with gates that stay open. Humanity is destined to live in a city that is defined but not defended, a city with clear borders but borders that are open.

Human guarding occurs under the guarding of God, Psalm 127 makes plain, and Psalm 82 pictures human authority as taking place under the judgment of God. God as judge directs those in authority to protect the vulnerable, especially the Hebrew Scriptures' trio of the widow, the orphan, and the migrant. In Deuteronomy 2-3, God is seen not only as judge but as the giver of land. God gives land to Israel and also to other nations, here to Edom, Moab, and Ammon. In this passage, the nations' lands are bordered, and entering them requires asking permission. These nations are given land to possess, to walk around in, where a people can be satisfied. Yet the God who gives them the land is just, and not only just, but has a particular love for the migrant, according to Deuteronomy 10. If the nations who receive land do not align themselves with God's justice, these nations can be dispossessed. On this interpretation of these passages, then, during this era between the garden of Eden and the New Jerusalem, God grants nations lands to possess and guard, yet those nations remain subject to God's judgement, including God's judgement against nations who do not treat migrants with justice.

Working with the grain of these biblical passages, the government of territory has its place in this era. To guard against the taking of human life, God authorises nations to protect territory, even to control migration into and out of that territory. Yet authority over immigration must be practiced humbly since God is the ultimate guard and authority. 
Immigration enforcement ought to protect human life and not only protect a culture or an economy. It also ought to recognise that most infractions against immigration laws count as mala prohibita, not mala in se, following the distinction of legal scholar William Blackstone.

That means that breaking immigration laws is not like murder, which is wrong in itself, but like breaking a speed limit, which is wrong because a government has established those laws. When nations enforce immigration laws not to punish serious wrong but rather to prevent some predicted future harm, say, the loss of a citizen's job, the usual punishment - deportation - is out of proportion to the wrong committed.

\section{Migrant neighbours}

So, protected borders have a legitimate role of protecting life in this time between Cain's city and the New Jerusalem, but immigration enforcement needs to proceed humbly, recognizing that it is subject to the judgement of the God who loves migrants. What then about relationships between settlers and migrants? The legal scholar's question to Jesus, 'Who is my neighbour? ${ }^{4}$ will touch members of a country in different ways, prompting them to ask: Who are the foreigners that I interact with regularly? Who already lives beside me, or who lives in the neighbouring country? With whom I am connected through the products I buy or the services I pay for? With whom am I tied through a common language or a history of conflict?

Surprising insights come from a fresh reading of the Parable of the Good Samaritan from Luke 10:25-37. The lawyer who questions Jesus would not have heard the command as 'love your neighbour as yourself but as 'love your compatriot as yourself. In Hebrew this quotation from Leviticus 19:18 uses rēa', meaning a friend, companion, or fellow member of the covenant. The lawyer would have thought that the command was to befriend and show love to a fellow member of Israel, or perhaps only to his sect within Israel. He would not have been ready for the bold interpretation that Jesus gave the command. In Luke's Greek, Jesus uses a word that means someone nearby, plēsion, so that the command is not just 'love your compatriot as yourself but 'love the one nearby you as yourself'. To address who is this man's neighbour, Jesus tells the story of a Samaritan, someone a Jewish person might consider apostate and a half-breed. Yet this Samaritan is the one who is so moved by the fallen man that he is hit in the gut. This Samaritan shows mercy to the bloodied man by the side of the road, taking him to an inn, probably at some danger to himself as an outsider. Jesus' story implies that the lawyer needs to start by imagining himself as the one who is beaten and weak, who has 
to accept help from the Samaritan. This hated half-foreigner is the one who becomes the neighbour, the one who turns out to be the neighbour.

Reflecting on the implications for migrant neighbours, the question 'Who is my neighbour?' is not aimed at causing hearers to consider whom they can show charity to. Listening to the parable, hearers are invited to imagine themselves as the person who is hurt and lying by the road. It turns out that the upstanding members of the hearers' community pass them by. Instead, a foreigner that they strongly dislike comes to their aid. Thus, when it comes to encounters between settled people and migrants, it is not the settled people who need to figure out how to show love to migrants. Instead, they might ask, which migrants are already showing me love and mercy? The parable puts the focus on encounters with those nearby that are easy to ignore, it places the power to act in the hated stranger's hands, and it shows that those strangers may be first to act as neighbours. Returning to the parable's frame, the question that the lawyer poses to Jesus about loving his neighbour in fact reveals something about loving God. Someone who learns to receive mercy from a neighbour is caught up in the love of the God who comes as the unexpected stranger Jesus. Receiving mercy from migrants - and along the way, imitating their mercy - draws one into receiving the love of God and returning that love.

\section{British immigration law and Christian ethics}

These theological insights came out of a dialogue with immigration law from the United States. That dialogue produces a few conclusions: that the church ought to identify with migrants rather than opposing itself to them; that immigration authority needs to be practiced humbly and with its proper end in sight; that settled persons need to recognise the mercy they have been shown by their migrant neighbours. What would a similar dialogue with British immigration law reveal? It would raise a few questions.

Firstly, can the churches of the United Kingdom stand in solidarity with migrants? Are the churches of England, Scotland, Wales, and Northern Ireland aware of the missionaries among them, those who go out as migrants to spread good news, and those who went out to found the churches they now worship in? Do they see themselves as grafted into Israel, who migrated to freedom from slavery in Egypt? Do they remember themselves as the 'visiting strangers and alien residents' of the early churches that Peter addresses in his first letter? ${ }^{5}$ I pose these questions especially to my own church, the Church of England. This is a church whose 
voice the Crown recognises by including bishops in the House of Lords, but whose migrant identity may be compromised when its clergy are required to swear that 'the Queen is the only supreme governor, as well in all spiritual and ecclesiastical things or causes as temporal'. ${ }^{6}$ If Her Majesty's government passes laws that mistreat those historically called 'aliens', the Church of England may have difficulty remaining a church that understands herself first as a migrant church.

But being a church of strangers welcoming strangers does not start with church leadership. It starts in the local church. Churches can include migrants in their worshipping life, moving quickly to invite them to do Scripture readings, pray, or lead worship. Rather than maintaining a sense that British people are hosts and migrants are always visitors, current church members can make efforts to include those from other countries as fellow members and leaders. Living out an identity as a migrant church may be as simple as having non-citizens lead intercessions or join a home group.

Secondly, are the churches calling on the Home Office to guard the United Kingdom in a humble manner? They can do this in a few ways. Restrictions on immigration ought to be directed at protecting human life, but all too often men and women are given the harsh punishment of deportation when they have lived a peaceable life and put down roots in the British Isles. Churches ought to continue to accompany and support people in immigration detention and people in jeopardy of being separated from their families because of a failure to meet requirements to renew their visas. What is more, the well-guarded islands of the United Kingdom have the capacity to include many more people fleeing conflict and persecution than the small numbers that are currently being received. ${ }^{7}$ Churches today have an opportunity to work with the Home Office through the Vulnerable Persons Resettlement Scheme, where communities sponsor a vulnerable refugee family arriving from Syria. Finally, this century has seen the growing internalisation of immigration controls, where immigration laws are not only enforced at the borders and airports, but landlords, employers, schools, universities, hospitals, and charities are required to check immigration documents. The churches and Christian charities have the opportunity resist the overbearing extension of immigration law into ordinary life, though this may come at a cost.

Thirdly, 'who are our neighbours'? How does the body of Christ in Britain respond to those perceived as foreign, and how have disliked foreigners shown love to settled people in 
these lands? When many voted for Brexit in 2016 because of opposition to European Union migration to the United Kingdom, Christians can ask where they have been shown mercy by EU citizens. Where, for example, have EU citizens provided farm labour or filled gaps in the skilled trades to keep Britons fed and housed? How, then, might British citizens recognise and receive the mercy they have been shown?

In a country with a history of trading slaves and building an empire, Britons are tied as 'neighbours' to people who live in many parts of the world. Since the Commonwealth Immigrants Act of 1962 was implemented, immigration from the Commonwealth has largely been limited to those with British ancestry. Yet in many ways, contemporary British life carries on through the work and goods gleaned from former colonial subjects who lack British ancestry. Christians can draw attention to this fact, and they can be especially attentive to descendants of those formerly colonised who live in the UK or seek entry to the UK. When a settled white British person considers a migrant from the West Indies whose ancestors Britons enslaved, it is not enough to say that British culture and institutions need to be preserved. For many years, British culture and institutions were dedicated to subjecting Black bodies to capture, family separation, forced labour, violence, and often death. In this case, being neighbours involves a long history in which a white person's ancestors grew wealthy while destroying the lives of the Black person's ancestors.

Similar questions arise between neighbours who are settled white British persons and South Asians who lived under British control and benefited British trade. Attention to history makes clear that only since 1994 was the number of people entering Britain consistently greater than the number leaving Britain. ${ }^{8}$ Reactions to immigrants currently in Britain need to be tempered by an historical awareness that Britons have been following opportunities abroad for centuries. Migrant neighbours, especially those who are disliked, scapegoated, or oppressed, have much to teach settled British people about being neighbours. The Parable of the Good Samaritan also promises that as British people receive mercy from migrant neighbours and return that mercy, both settled people and migrants will be drawn further into the love of God.

In conclusion, a theological dialogue with immigration law highlights the importance of the people of God as a migrant people and the destiny of the nations as coming together in the blood of Christ. This dialogue also highlights a church posture toward government that the control of immigration is to be undertaken only in a limited way that keeps in mind the 
purpose of migration controls to protect human life and no more. Finally, the dialogue highlights the importance of asking 'Who is my neighbour?', pointing Christians to recognise those foreigners who have shown them mercy. This dialogue began with US law, but a parallel dialogue with British law produces new conclusions. From the parishes to the bishops, the church is invited to live out her identity as a migrant church and to avoid collusion with distorted nationalisms while seeking the welfare of the nations of the United Kingdom. In proclaiming that Christ is king, these churches have reason to press the Home Office to share the safety and prosperity of Britain with refugees and to facilitate refugee resettlement, while resisting overbearing acts of immigration control like unjust deportations and internalised border controls. And Christians need to lead the way in asking 'Who is my neighbour?', valuing the gifts they have received from EU migrants and other current migrants as well as from the descendants of the British Empire's slaves and colonial subjects. In these actions, the churches have the opportunity to remember who they are as God's beloved people.

\section{Author biography}

Dr Robert W. Heimburger (robert.heimburger@abdn.ac.uk) immigrated from the United States to the United Kingdom. He is Postdoctoral Research Fellow in Theological Ethics at the University of Aberdeen.

\footnotetext{
${ }^{1}$ Karl Barth, Church Dogmatics, ed. G. W. Bromiley and T. F. Torrance, trans. A. T. Mackay et al., vol. III/4, The Doctrine of Creation (Edinburgh: T. \& T. Clark, 1961), 302, in the context of pp. 285-323.

${ }^{2}$ Ephesians 2:13-14, ESV.

${ }^{3}$ Brian Brock and Bernd Wannenwetsch, The Malady of the Christian Body: A Theological Exposition of Paul's First Letter to the Corinthians, vol. 1 (Eugene, Ore.: Cascade, 2016), p. 215.

${ }^{4}$ Luke 10:29.

${ }^{5} 1$ Peter 2:11, author's translation.

${ }^{6} 1^{\circ}$ Elizabeth, cap. 1, The Statutes of the Realm, vol. 4, pt. 1 (London: George Eyre and Andrew Strahan, 1819), p. 352.

7 'The UK granted asylum, alternative forms of protection, or resettlement to 15,170 people in the year ending September 2018' according to the 'Migration Statistics Quarterly Report' (United Kingdom: Office for National Statistics, 2018),

https://www.ons.gov.uk/peoplepopulationandcommunity/populationandmigration/internationalmigration/bulle tins/migrationstatisticsquarterlyreport/latest. By contrast, the population of those forcibly displaced from their homes around the world at the end of 2017 was 68.5 million, or greater than the population of the UK, 'Forced Displacement in 2017', Global Trends (Geneva: UNHCR, 2018), https://www.unhcr.org/globaltrends2017/.

${ }^{8}$ Madeleine Sumption and Carlos Vargas-Silva, 'Long-Term International Migration Flows to and from the UK', Migration Observatory briefing (Oxford: COMPAS, University of Oxford, 2018), https://migrationobservatory.ox.ac.uk/resources/briefings/long-term-international-migration-flows-to-and-fromthe-uk/; 'Long-Term International Migration 2.00, Citizenship, UK' (United Kingdom: Office for National Statistics, 2018),

https://www.ons.gov.uk/peoplepopulationandcommunity/populationandmigration/internationalmigration/data sets/longterminternationalmigration200citizenshipuk.
} 